\title{
Phytoremediation efficiency of water hyacinth (E. crassipes), canna ( $C$. indica) and duckweed (L. minor) plants in treatment of sewage water
}

\author{
Bhutiani R., ${ }^{1}$ Rai N., ${ }^{2}$ Sharma P. K., ${ }^{3}$ Rausa K. ${ }^{2}$ and Ahamad F. ${ }^{1} \bowtie$
}

Received: 29.09 .2018

Revised: 23.01.2019

Accepted: 19.04.2019

\begin{abstract}
Due to the continuous increase in industrialisation and urbanization, wastewater has been released regularly into the environment in excess amount, causing noteworthy impacts on human and wild life. Management and eco-friendly treatment of the waste water whether industrial and domestic is the challenge of this century. In the present study an attempt has been made to treat the waste water using three aquatic macrophytes viz. water hyacinth (Eichhornia crassipes), canna (Cana indica) and duckweed (Lemna minor) for assessing the potential of these plants in the treatment of sewage collected from drain located nearby Graphic Era University, Dehradun using phytoremediation technology on the basis of different physicochemical parameters such as pH, EC, DO, ORP, Salinity, TDS, BOD, COD, Hardness and Temperature. The study was divided into seven consecutive assessment periods of five days interval each. Highest removal was observed in the experiment containing canna in each parameters which suggest that in the present study canna $(C$. indica) was found most efficient plant in comparison to $E$. crassipes and $L$. minor. The capability of these plants in the treatment of wastewater was established from the study. For efficient water purification, it is recommended to remove the aquatic macrophytes from water bodies. If the harvesting of these aquatic macrophytes will not be performed properly, the vast majority of the nutrients that have been absorbed and stored into the plant tissue will released again into the water bodies due to decomposition of these macrophytes.
\end{abstract}

Key words: Harvesting, Eichhornia crassipes, IWMI, $O$ and M problem, sullage.

\section{Introduction}

On one hand the need of water is growing day by day while on the other hand scarcity of water resources is continuously growing in the world. The International Water Management Institute (IWMI) predicts that by 2025 , one person in three will live in conditions of absolute water scarcity only in India. Approximately 61754 MLD sewage, was generated during 2015 in the country. Out of this sewage only $38 \%$ was treated (22963 MLD) and about 62\% (38791 MLD) of the total sewage was released directly into the environment. Primary treatment facilities are available only in Twenty seven cities and forty-nine have primary and secondary treatment facilities. The level of treatment available in cities with existing treatment Author's Address

${ }^{1}$ Limnology and Ecological Modelling Lab. Department of Zoology \& Environmental Sciences, Gurukula Kangri Vishwavidyalaya, Haridwar - 249404 , Uttarakhand, India.

${ }^{2}$ Department of Biotechnology, Graphic Era (Deemed to be University), Dehradun- 248002, Uttarakhand, India.

${ }^{3}$ Department of Environmental Science, Graphic Era (Deemed to be University), Dehradun- 248002, Uttarakhand, India. E-mail.: faheem.rs@gkv.ac.in plant varies from $2.5 \%$ to $89 \%$ of the sewage generated (Source: ENVIS centre on Hygiene, Sanitation, Sewage Treatment Systems and Technology).

Status on Sewage Generation in Metropolitan Cities, Class-I Cities and Class-II Towns: The data indicate that due to population explosion, huge volume of sewage is being produced in metropolitan cities. Discharge of untreated sewage both in surface and ground waters is the most important water polluting source in India (Bhutiani et al., 2016). There is a large gap between per day sewage generation and treatment capacity (Out of 100 only 32\%) in India. Even the existing treatment facilities are facing operation and maintenance problem (O and $\mathrm{M})$ due to absence of skill and poor economic conditions (nearly 39\% plants are not conforming to the general standards prescribed under the Environmental (Protection) Rules for discharge into streams as per the CPCB's survey report). Auxiliary power back-up facility is required at all the intermediate (IPS) and main pumping 
stations (MPS) of all the STPs. Approximately $81 \%$ of the water supplied to the 299 class I returned as sewage (16,662 MLD). The reuse of wastewater is a valuable economical source of water in developing countries like India (Bhutiani and Ahamad, 2018). Due to high capital and maintenance costs, with no economic return, the available technologies are unaffordable. In India only in $4 \%$ (only 232 out of 4700 towns / cities), have the sewerage system, and that too only partial. Most of the untreated waste water is, therefore, discharged directly into river bodies or other water surface or underground water bodies. Sue lack of awareness and treatment facilities most of the sewage and sullage generated in rural areas discharged directly in to the open water bodies such as pond, which caused the problem of eutrophication in these water bodies due to excess of nitrate and phosphates. Thus in developing countries like India simple, easy to use and costeffective technology of waste water purification is on high demand. One of the treatment technologies meeting all these parameters is 'Phytoremediation' for purification of waste water. Phytoremediation is the biological treatment of wastewater (Roongtanakiat et al., 2007), based on the concept of using plants and microbiological processes to remove contaminants from the nature. Phytoremediation techniques relies on specific planting arrangements of plants, constructed wetlands (CW), floating-plant systems and numerous other configurations (Cunningham et al., 1995). Different removal mechanisms like sedimentation, filtration, chemical precipitation, adsorption, microbial interactions and uptake of vegetation are involved in in this technology (Hammer, 1989). Nowadays due to low cost and low energy requirement for sewage treatment phytoremediation has become popular among all treatment technologies (Sooknah and Wilkie, 2004; Padmapriya and Murugesan, 2012; Kumar and Chopra, 2016, Kumar et al., 2016). Selection of an appropriate plant having high removal capacities both for organic and inorganic pollutants is the most important factor in implementing the phytoremediation for waste water treatment (Roongtanakiat et al., 2007, Stefani et al., 2011).The uptake and accumulation of pollutants vary from plant to plant and also from specie to species within a genus (Singh et al., 2003). The economic success of phytoremediation largely depends on photosynthetic activity and growth rate of plants (Xia and Ma, 2006) and with low to moderate amount of pollution (Jamuna and Noorjahan, 2006). Aquatic macrophytes treatment systems for waste-water are the need of developing countries, because they are cheaper to construct and a little skill is required to operate (Mahmood et al., 2005) and they remove the pollutant by absorbing nutrients with their effective root system (Dhote and Dixit, 2007; Schulz et al., 2003). The most common aquatic macrophytes among the floatingleaved, being employed in wastewater treatment are water hyacinth, Canna, water lettuce and Lemna (John et al., 2008; Maine et al., 2004; Mishra et al., 2008).

Eichhornia crassipes: Water hyacinth (E. crassipes) is a productive free floating aquatic weed (Wolverton and McDonald, 1979) is perennial macrophytes has a very fast growth rate (Reddy and Sutton, 1984; APIRIS 2005; Patil et al., 2011; Dhote and Dixit, 2009). Water hyacinth is considered as an unpleasant weed and attracted the whole world attention due to its fast growth leading to serious problems in navigation, irrigation, and power generation (Dar et al., 2011; Villamagna, 2009). About $60-70 \%$ of the total biomass is represented by the leaves of the plant and the leaf turnover rate can range from $60-70 \%$ per month. Water hyacinth has been successfully applied not only in removing organics and metals but also act as a bio indicator for assessment of metal pollution. It is seen that water hyacinth has a tremendous capacity of absorbing metals like copper, cadmium, zinc, iron, mercury, arsenic and lead. There is shortage of water throughout the world. Therefore, there is a need for recycling of waste water i.e., the use of reclaimed waste water whenever possible. E. crassipes is an aquatic plant having good feasibility of phytoremediation of wastewaters containing metallic and other kind of chemical pollutants (Kumar et al., 2017a, b).

C. indica (Wild Cana Lily): In Maharashtra $C$. indica is commonly known as, 'Kardali'. Macrophytes $C$. indica is a perennial herb with tuberous root. These macrophytes commonly grow naturally near open streams, near houses and along riverbanks. The plant prefers a sheltered situation. It also grows perfectly in direct sunlight, and 


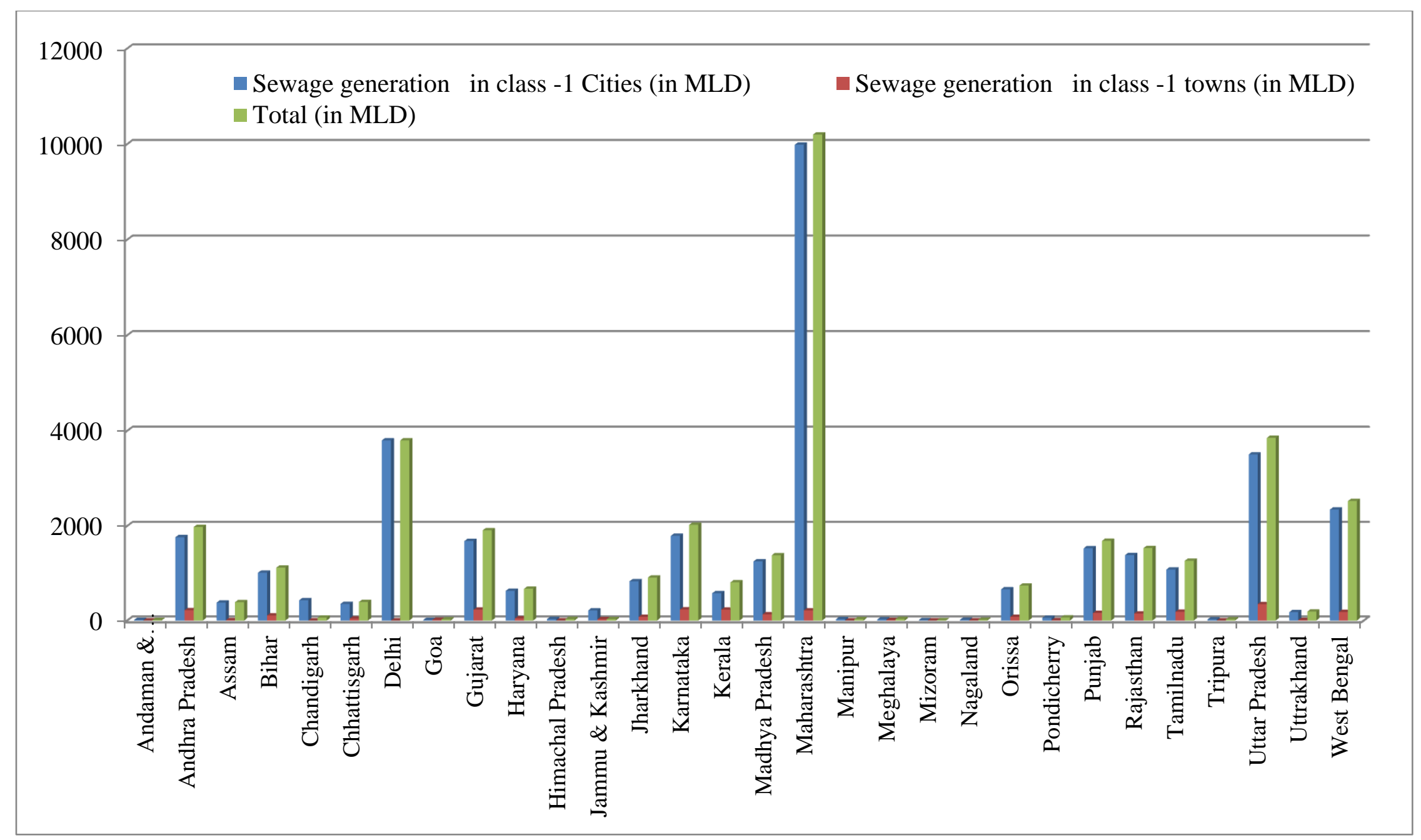

Fig 1. State-wise sewage generation of Class-I Cities and Class-II Towns

Source: http://www.cpcb.nic.in/upload/NewItems/NewItem_153_Foreword.pdf 
prefers medium depth levels of water. Cana indica grows in the soils of varied range of $\mathrm{pH}$ ranging from a $\mathrm{pH}$ of 5 to 8.5. It is adapted to a wide variety of soil type such as chalk, clay, clay loam, loam, loamy sand, peat, sandy clay, sandy clay loam and sandy loam soils. It has a clump forming growth form, and has an ultimate height of $2 \mathrm{~m} / 6.6 \mathrm{ft}$ and spread of $0.5 \mathrm{~m} / 1.6 \mathrm{ft}$.

Lemna minor (Duck weed): L. minor commonly grows in motionless or slow-flowing, nutrientenriched waters through-out tropical and temperate zones. Suitable growth conditions for L. minor include temperatures range of $6-33^{\circ} \mathrm{C}$, a wide $\mathrm{pH}$ range with optimal growth between $\mathrm{pH} 5.5$ and 7.5 (Mkandawire and Dudel, 2005a, 2005b). L. minor are the dominant primary producer in Lemnatae type of macrophytic communities, a quartz "monospecific" plant association (Landolt, 1980, 1982, 1986; Les et al., 2002). Their advance but simple anatomical and physiological structure has scientific and engineering significance. These properties allow easy handling, and manipulating under laboratory conditions. Lemna is a small freefloating and fast growth aquatic plant has great ability to reduce the BOD, COD, suspended solids, bacterial and other pathogens from waste water. Reduction of BOD, COD in effluents varies from $80-90 \%$ at the retention time of 7-8 days. Of these, applications of duckweed in wastewater treatment was found to be very effective in the removal of nutrients, soluble salts, organic matter, heavy metals and in eliminating suspended solids, algal abundance and total and fecal coliform densities (Nieder et al., 2004; Selvarathi and Ramasubramanian, 2010). The main aim of this study was to explore the phytoremediation potential of E.crassipes, C.indica and L.minor in treatment of sewage waste water.

This followed the underlying objectives:-

1. To assess phytoremediation potential of $E$. crassipes, $C$. indica and $L$. minor in treatment of sewage waste water.

2. To investigate effect of phytoremediation on physico-chemical characteristics of sewage waste water.

\section{Materials and Methods}

Collection of wastewater: Wastewater samples were collected from sewage drain located nearby
Graphic Era University, Dehradun. These wastewater samples were distributed in 4 plastic tubs. 3 plants namely, Eichhornia, Canna and Lemna were chosen for the current study. All the physicochemical parameters were analyzed using standard methods described by APHA, 2012: Trivedy and Goel, 1986 and Khanna and Bhutiani, 2008.

Collection of Macrophytes: E. crassipes and L.minor was collected from Gang Nahar Canal, Roorkee whereas C.indica was collected from sewage drain of Graphic Era university campus. All three macrophytes were collected on the same day and brought to laboratory for experimental setup. Before starting the experiment, plants was thoroughly washed with tap water followed by distill water and finally roots were rinsed with acetone to avoid any contamination.

Experimental Setup: Plastic tubs, of round shape, 5 litre capacity were selected for starting experiment. Tubs were properly washed and dried with tissue. 5 litres of waste water was filled in all tubs. Tub 1 was fixed as a control and it was without any plant. E. crassipes was grown in tub 2 , $C$. indica plant was grown in tub 3 and L. minor was put in tub 4 (Fig 3). Samples were taken after every 3 days separately from all four tubs and were analyzed for $\mathrm{pH}, \mathrm{EC}$, DO, ORP, salinity, TDS, BOD, COD and temperature. This assessment was carried out for 30 days at a regular interval of 3 days. Along with this microbial CFU count was carried out in laboratory of Biotechnology at Graphic Era University before and after the final treatment. Furthermore, genera of gram negative rods were identified in waste water.

Salinity and TDS of the wastewater sample was measured using Multipara meter system of model no. SensION+ MM 150. Each time before taking the reading, calibration of the instrument was done. The measurements were taken at regular intervals of 3 days. Rest of the parameters was analyzed using titrimetry and spectrophotometry technique.

\section{Results and Discussion}

Physico-chemical characteristics of waste water

Before starting the experiments, physic-chemical analysis of waste water was carried out in the laboratory. Waste water was analyzed for $\mathrm{pH}$, 
temperature, electrical conductivity (EC), oxidation-redox potential (ORP), dissolved oxygen
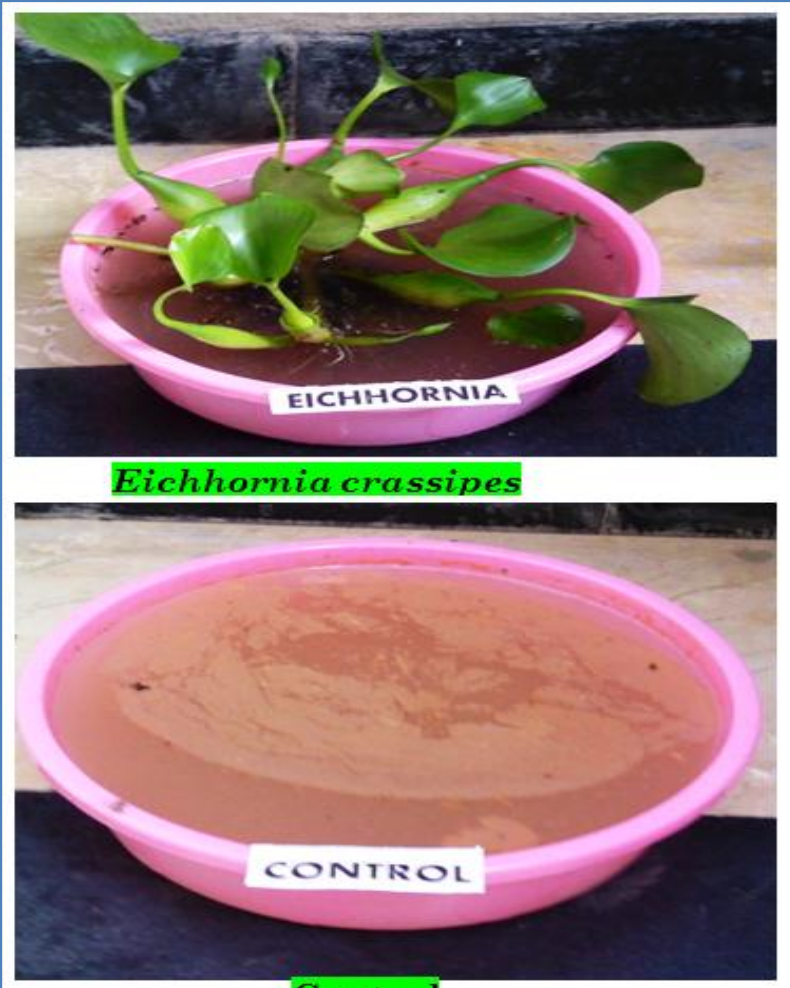

Control

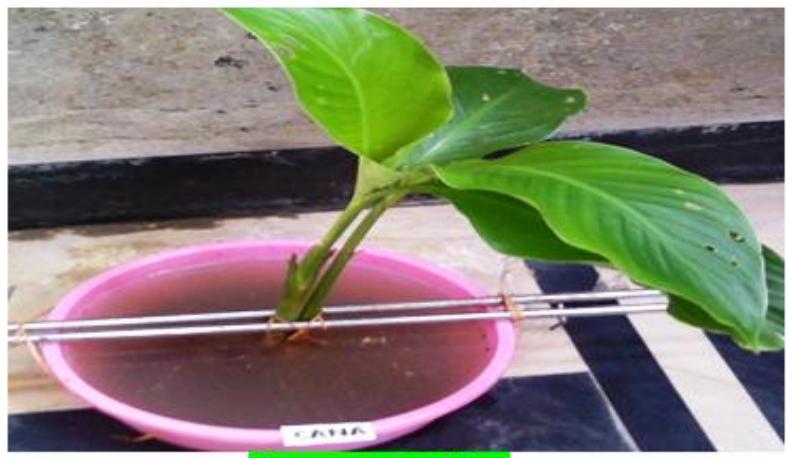

Canna indica

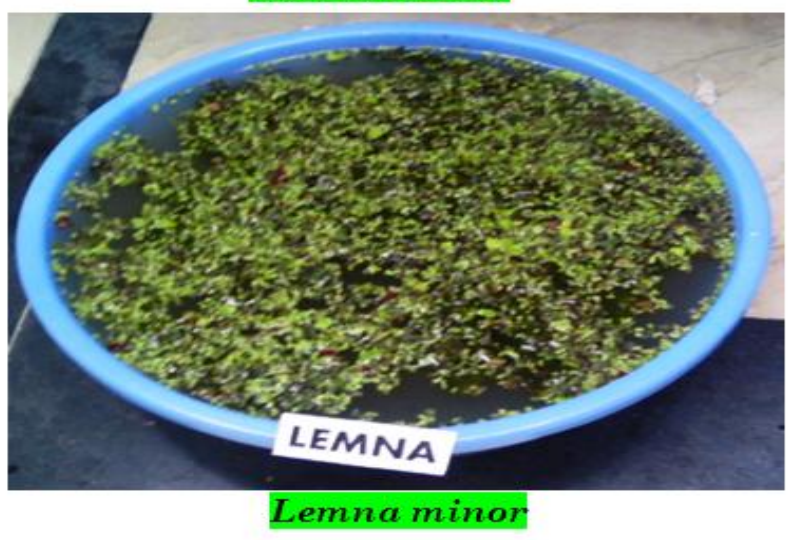

Fig 2. Experimental set up for treatment of sewage waste water by E.crassipes, C.indica, L. minor along with control.

(DO), biochemical oxidation demand $\left(\mathrm{BOD}_{5}\right)$, chemical oxidation demand (COD), salinity, total dissolve solids (TDS), hardness (as $\mathrm{CaCO}_{3}$ ) (Table 5.1)

pH: During assessment period a decrease was observed in $\mathrm{pH}$ in control experiment as well as in all the three treatments i.e. Eichhornia crassipes, Canna indica and Lemna minor. In control experiment $\mathrm{pH}$ was decreased from $7.69 \pm 0.02$ to $7.32 \pm 0.03$ from initial to final assessment (Table 2). Maximum decrease of 0.05 unit was recorded between $21^{\text {st }}$ to $24^{\text {th }}$ and $24^{\text {th }}$ to $27^{\text {th }}$ day of assessment period whereas minimum decrease of 0.01 unit was recorded between $1^{\text {st }}$ to $3^{\text {rd }}, 15^{\text {th }}$ to $18^{\text {th }}$ and $27^{\text {th }}$ to $30^{\text {th }}$ day of assessment period. A total of 0.37 unit decrease in $\mathrm{pH}$ was observed during entire assessment period (Fig 3).

In the experiment containing Eichhornia crassipes, $\mathrm{pH}$ was changed from $7.6 \pm 0.03$ to $7.16 \pm 0.02$ throughout assessment period. Maximum decrease of 0.08 unit was recorded between $15^{\text {th }}$ to $18^{\text {th }}$ day of treatment, whereas minimum decrease of 0.03 unit was observed between $27^{\text {th }}$ to $30^{\text {th }}$ day of assessment. Entire Eichhornia treatment resulted into a decrease of 0.44 unit in wastewater $\mathrm{pH}$. Canna treatment showed a change in wastewater $\mathrm{pH}$ from 7.6 \pm 0.03 to $7.16 \pm 0.01$ during experimental period. Maximum decrease of 0.07 unit was recorded between $12^{\text {th }}$ to $15^{\text {th }}$ day of treatment, however minimum decrease of 0.01 unit was observed between $27^{\text {th }}$ to $30^{\text {th }}$ day of assessment. Overall, Canna treatment showed a $\mathrm{pH}$ decrease of 0.49 unit which was maximum among all treatments. Microbial degradation in the waste water results into conversion of organic matter into acids which decreases $\mathrm{pH}$ of waste water. This is confirmed in all treatments. Results show that maximum microbial degradation occurred in Canna treatment. Lemna treatment also resulted into similar pattern of $\mathrm{pH}$ decrease from initial to final day of treatment. $\mathrm{pH}$ changed from $7.6 \pm 0.03$ to $7.16 \pm 0.02$ during assessment period. This change was very close to Canna treatment. Lemna treatment showed a maximum decrease of 0.09 unit 
Table 1. Physico-chemical characteristics of sewage waste water

\begin{tabular}{|l|l|l|l|}
\hline SN & Parameter & Unit & Value \\
\hline 1. & $\mathrm{pH}$ & - & 7.69 \\
\hline 2. & Electrical Conductivity (EC) & $\mu \mathrm{S} / \mathrm{cm}$ & 1534.0 \\
\hline 3. & Oxidation-Redox potential (ORP) & $\mathrm{mV}$ & -69.1 \\
\hline 4. & Total dissolved solids (TDS) & $\mathrm{mg} / \mathrm{L}$ & 983.0 \\
\hline 5. & Salinity & $\mathrm{mg} / \mathrm{L}$ & 785.0 \\
\hline 6. & Biochemical oxygen demand $\left(\mathrm{BOD}_{5}\right)$ & $\mathrm{mg} / \mathrm{L}$ & 252.0 \\
\hline 7. & Chemical oxygen demand $(\mathrm{COD})$ & $\mathrm{mg} / \mathrm{L}$ & 345.0 \\
\hline 8. & Dissolved oxygen $(\mathrm{DO})$ & $\mathrm{mg} / \mathrm{L}$ & 2.2 \\
\hline 9. & Hardness $\left(\right.$ as $\left.\mathrm{CaCo}_{3}\right)$ & $\mathrm{mg} / \mathrm{L}$ & 230.0 \\
\hline 10. & Temperature & ${ }^{0} \mathrm{C}$ & 23.5 \\
\hline
\end{tabular}

between $12^{\text {th }}$ to $15^{\text {th }}$ day of assessment while minimum decrease of 0.01 unit was recorded between $15^{\text {th }}$ to $18^{\text {th }}$ and $27^{\text {th }}$ to $30^{\text {th }}$ day of assessment period. Among all three treatments Canna treatment showed maximum decrease in $\mathrm{pH}$ followed by Lemna, Eichhornia and control treatment. Similar findings were observed by Mahmood et al., 2005.

Electrical Conductivity (EC): During assessment period, EC was changed from $1534.0 \pm 7.0$ to $1482.0 \pm 4.0 \mu \mathrm{S} / \mathrm{cm}$ in control; $1529.0 \pm 6.0$ to $958.0 \pm 3.0 \mu \mathrm{S} / \mathrm{cm}$ in Eichhornia; $1534.0 \pm 7.0$ to $750.0 \pm 2.0 \mu \mathrm{S} / \mathrm{cm}$ in Canna and $1545.0 \pm 5.0$ to $811.0 \pm 5.3 \mu \mathrm{S} / \mathrm{cm}$ in Lemna treatment (Fig 4 and Table 2). In control, EC showed a maximum decrease of $9.0 \mu \mathrm{S} / \mathrm{cm}$ between $24^{\text {th }}$ to $27^{\text {th }}$ day of treatment, whereas minimum decrease of $2.0 \mu \mathrm{S} / \mathrm{cm}$ was found between $1^{\text {st }}$ to $3^{\text {rd }}$ and $15^{\text {th }}$ to $18^{\text {th }}$ day of treatment. However Eichhornia treatment showed great fluctuations in the pattern of decrease in EC value during assessment period. Maximum decrease of $218.0 \mu \mathrm{S} / \mathrm{cm}$ was observed between $9^{\text {th }}$ to $12^{\text {th }}$ day of assessment period and minimum decrease of $9.0 \mu \mathrm{S} / \mathrm{cm}$ was recorded between $1^{\text {st }}$ to $3^{\text {rd }}$ and $27^{\text {th }}$ to $30^{\text {th }}$ day of treatment. Eichhornia plant could not survive after $18^{\text {th }}$ day of treatment which resulted into less decrease in EC afterwards compared to previous days of treatment. An average of $19.0 \mu \mathrm{S} / \mathrm{cm} /$ day $\mathrm{EC}$ reduction was observed during 30 days of treatment. More or less similar results were observed by Borgs et al., 2008. In Canna treatment, Maximum decrease of 131.0 $\mu \mathrm{S} / \mathrm{cm}$ was observed in EC between $9^{\text {th }}$ to $12^{\text {th }}$ day of treatment while minimum EC reduction of 15.0 $\mu \mathrm{S} / \mathrm{cm}$ was observed between $24^{\text {th }}$ to $27^{\text {th }}$ day of treatment. Canna treatment showed an average decrease of $26.13 \mu \mathrm{S} / \mathrm{cm} /$ day in EC during assessment period. Lemna treatment also exhibited similar trend of EC decrease during treatment period. Maximum decrease of $111.0 \mu \mathrm{S} / \mathrm{cm}$ in EC was recorded between $18^{\text {th }}$ to $21^{\text {st }}$ day of treatment. Minimum EC reduction of $51.00 \mu \mathrm{S} / \mathrm{cm}$ was found between $27^{\text {th }}$ to $30^{\text {th }}$ day of treatment. Average EC decrease of $24.46 \mu \mathrm{S} / \mathrm{cm} /$ day was observed in Lemna treatment. Among all three treatments Canna showed maximum reduction in EC followed by Lemna, Eichhornia and Control. EC reduction occurs as result of nutrient uptake of macrophytes and it suggests that Canna has highest nutrient uptake potential among Eichhornia and Lemna.

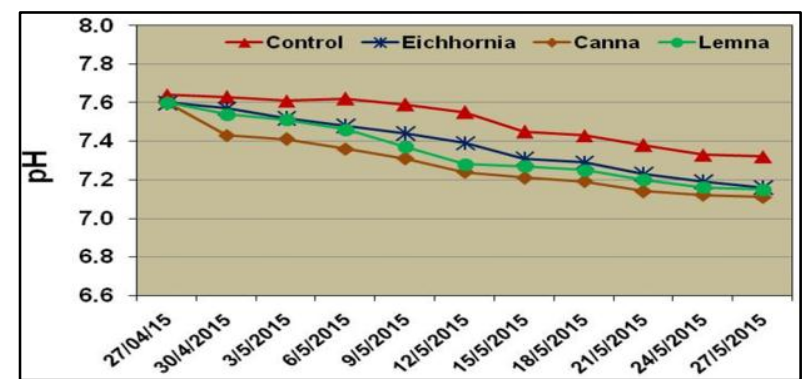

Fig 3. Change in $\mathrm{pH}$ of sewage during the treatment process by Eichhornia, Canna and Lemna.

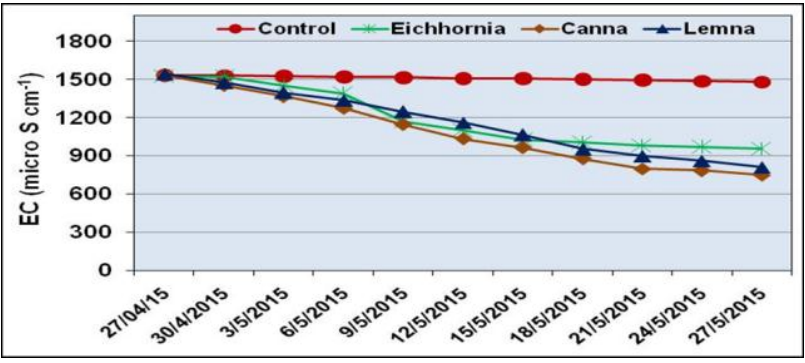

Fig 4. Change in EC of sewage during the treatment process by Eichhornia, Canna and Lemna. 
Oxidation-Redox potential (ORP): During assessment period, ORP was changed from $-68.3 \pm-$ 3.3 to $-48.2 \pm-2.5 \mathrm{mV}$ in control, $-68.7 \pm-4.3$ to $31.9 \pm-2.8 \mathrm{mV}$ in Eichhornia, $-72.5 \pm-4.2$ to $-12.8 \pm-$ $2.1 \mathrm{mV}$ in Canna and $-77.2 \pm 5.4$ to $-16.3 \pm-2.5 \mathrm{mV}$ in Lemna (Fig 5 and Table 2). Average ORP change of $-0.67,-1.23,-1.99$ and $-2.03 \mathrm{mV} /$ day was observed in control, Eichhornia, Canna and Lemna treatment during study period respectively. In control treatment, maximum ORP change of -5.8 $\mathrm{mV}$ was observed between $21^{\text {st }}$ to $24^{\text {th }}$ day of treatment, whereas, minimum change of $-0.3 \mathrm{mV}$ was recorded between $6^{\text {th }}$ to $9^{\text {th }}$ day of assessment. In Eichhornia treatment, maximum change of -9.8 $\mathrm{mV}$ was observed between $15^{\text {th }}$ to $18^{\text {th }}$ day of study period whereas minimum ORP change $-0.6 \mathrm{mV}$ in this treatment was observed between $12^{\text {th }}$ to $15^{\text {th }}$ day of assessment.

In Canna treatment, ORP change between two consecutive assessment periods fluctuated between -1.2 to $-16.8 \mathrm{mV}$. Highest ORP change was observed between $1^{\text {st }}$ to $3^{\text {rd }}$ day of treatment while lowest ORP change of $-1.2 \mathrm{mV}$ was found between $18^{\text {th }}$ to $21^{\text {st }}$ and $24^{\text {th }}$ to $27^{\text {th }}$ day of treatment. ORP change was observed in all treatments due to oxidation of organic matter by microbial action. Highest ORP change in Canna treatment reflects maximum microbial action in this treatment in terms of degradation of organic waste present in waste water.

Total dissolved solids (TDS): TDS concentration was decreased from $983.0 \pm 10.0$ to $856.0 \pm 6.0 \mathrm{mg} / \mathrm{L}$ in control, $978.0 \pm 12$ to $342.0 \pm 6.0 \mathrm{mg} / \mathrm{L}$ in Eichhornia, $967.0 \pm 11$ to $243.0 \pm 4.0$ in Canna and $961.0 \pm 8.0$ to $298.0 \pm 5.0 \mathrm{mg} / \mathrm{L}$ in Lemna treatment during treatment period (Table 2). Highest TDS removal was achieved by Canna while control treatment showed lowest TDS removal during assessment period. Average TDS removal per day was observed as 4.2, 21.2, 24.1 and $22.1 \%$ in control, Eichhornia, Canna and Lemna (Fig 6). Except control treatment, rest three treatments showed more or less similar TDS removal efficiency during treatment period.

Control treatment showed 1.0 to $65.0 \mathrm{mg} / \mathrm{L}$ of TDS removal between two consecutive assessment periods. Highest TDS removal was observed between $3^{\text {rd }}$ to $6^{\text {th }}$ day of treatment however lowest removal was recorded between $21^{\text {st }}$ to $24^{\text {th }}$ day of assessment. Eichhornia treatment provided higher fluctuations in TDS removal between two consecutive treatment periods compared to control treatment. Maximum TDS removal of $174.0 \mathrm{mg} / \mathrm{L}$ was observed between $9^{\text {th }}$ to $12^{\text {th }}$ day of treatment whereas minimum removal of $2.0 \mathrm{mg} / \mathrm{L}$ was recorded between $27^{\text {th }}$ to $30^{\text {th }}$ day. After $15^{\text {th }}$ day of treatment TDS removal rate dropped down significantly due of death of Eichhornia crassipes experimental pot. This reveals that macrophytes contribute significantly in TDS removal from wastewater. More or less similar results were observed by Borgs et al., 2008.

In Canna treatment, TDS removal rate showed more compromising results compared to other treatments. TDS removal rate fluctuated between 31 to $150 \mathrm{mg} / \mathrm{L}$ between two consecutive treatment periods. Maximum TDS removal of $150.0 \mathrm{mg} / \mathrm{L}$ was recorded between $3^{\text {rd }}$ to $6^{\text {th }}$ day of treatment while minimum removal was observed between $27^{\text {th }}$ to $30^{\text {th }}$ day of assessment. Lemna treatment showed more consistent results in terms of TDS removal between two consecutive assessment periods. TDS removal fluctuated between 14.0 to $79.0 \mathrm{mg} / \mathrm{L}$ between two consecutive assessment periods. From initial day of treatment upto $18^{\text {th }}$ day of treatment TDS removal consistently remained between 70.0 to $70.9 \mathrm{mg} / \mathrm{L}$ in consecutive assessment periods. Highest TDS removal was achieved in 3 consecutive assessment periods i.e. between $1^{\text {st }}$ to $3^{\text {rd }}$ day, $3^{\text {rd }}$ to $6^{\text {th }}$ day and $15^{\text {th }}$ to $18^{\text {th }}$ day of treatment. Lowest TDS removal of 14.0 $\mathrm{mg} / \mathrm{L}$ was recorded between $27^{\text {th }}$ to $30^{\text {th }}$ day of treatment. Total dissolved solids are measure of all dissolved solutes in waste water. As plants grow in waste water it absorb dissolved salts from the waste water through its root system which results into decrease in TDS concentration with time (Greongerg et al., 1995). Maximum TDS reduction was observed in Canna treatment which shows the efficient potential of Canna indica in absorption of salts from waste water.

Salinity: Salinity is the amount of all the dissolved salts present in the in the wastewater. Salinity

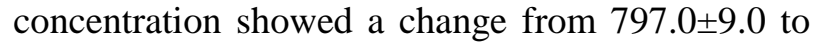
$723.0 \pm 4.0 \mathrm{mg} / \mathrm{L}$ in control, $757.0 \pm 8.0$ to $284.0 \pm 3.0$ $\mathrm{mg} / \mathrm{L}$ in Eichhornia, $745.0 \pm 11.0$ to $146.0 \pm 5.0 \mathrm{mg} / \mathrm{L}$ in Canna and $735.0 \pm 8.0$ to $184.0 \pm 3.0 \mathrm{mg} / \mathrm{L}$ in Lemna treatment (Fig 7 and Table 2). Average salinity removal per day was recorded as $2.5,15.8$, 20.0 and $18.4 \%$ in control, Eichhornia, Canna and 
Lemna treatment respectively. Canna and Lemna showed more or less similar removal of salinity during treatment period. In control treatment, highest salinity removal of $13.0 \mathrm{mg} / \mathrm{L}$ was achieved between $3^{\text {rd }}$ to $6^{\text {th }}$ day of treatment whereas lowest salinity removal was recorded between $21^{\text {st }}$ to $27^{\text {th }}$ day of treatment. Eichhornia treatment showed a high range of fluctuations in salinity removals between consecutive assessment periods; as high as $185.0 \mathrm{mg} / \mathrm{L}$ removal was observed between $9^{\text {th }}$ to $12^{\text {th }}$ day of treatment and as low as $3.0 \mathrm{mg} \mathrm{L}^{-1}$ between $21^{\text {st }}$ to $24^{\text {th }}$ and $27^{\text {th }}$ to $30^{\text {th }}$ day of treatment. Canna treatment showed highest removal of salinity among all treatments and provided removal fluctuations between 19.0 to $109.0 \mathrm{mg} / \mathrm{L}$ removal between consecutive assessment periods. Maximum removal was achieved between $6^{\text {th }}$ to $9^{\text {th }}$ day of treatment whereas minimum removal was recorded between $27^{\text {th }}$ to $30^{\text {th }}$ day of treatment period. Lemna treatment also provided compromising results for salinity and was close to Canna treatment. Furthermore, removal efficiency was more consistent in Lemna treatment and fluctuated between 14.0 to $91.0 \mathrm{mg} / \mathrm{L}$ between two consecutive assessments. Higher removals were achieved between $6^{\text {th }}$ to $18^{\text {th }}$ day of treatment.

Plants absorb dissolved salts from the waste water through at their root zone which leads to decrease in salinity in waste water. Absorbed salts are used by plants as macronutrients. Maximum salinity reduction was observed in Canna treatment which shows that Canna indica has high capability in absorption of salts from waste water.

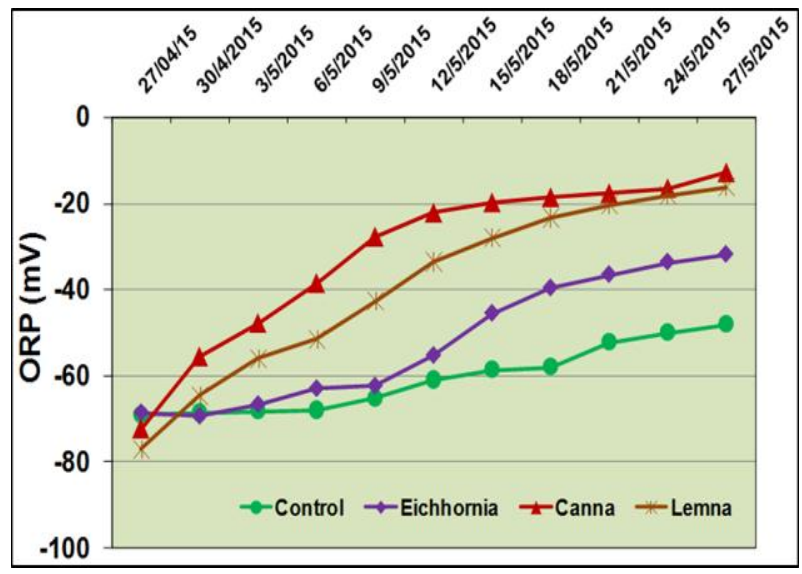

Fig 5. Change in ORP of sewage during the treatment process by Eichhornia, Canna and Lemna.

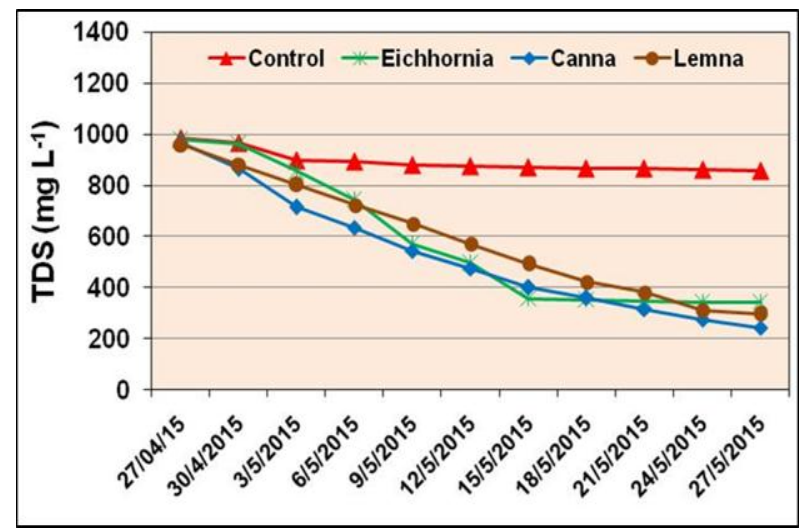

Fig 6. Change in TDS of sewage during the treatment process by Eichhornia, Canna and Lemna.

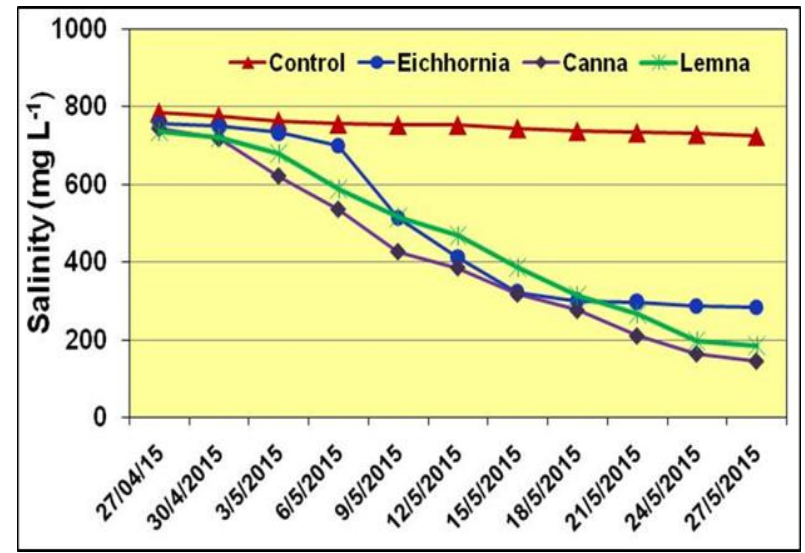

Fig 7. Change in Salinity of sewage during the treatment process by Eichhornia, Canna and Lemna.

Biochemical Oxygen Demand (BOD): BOD value in control, Eichhornia, Canna and Lemna treatment showed a decrease from $252.0 \pm 8.0$ to $218.0 \pm 6.5$ $\mathrm{mg} / \mathrm{L}, 251.0 .0 \pm 5.9$ to $150.0 \pm 8.2 \mathrm{mg} / \mathrm{L}, 246.0 \pm 6.7$ to $65.0 \pm 2.5 \mathrm{mg} / \mathrm{L}$ and $251.0 \pm 4.6$ to $79.0 \pm 3.3 \mathrm{mg} / \mathrm{L}$ respectively (Fig 8 and Table 2). A more or less similar trend in COD reduction was observed by Deshmukh et al., 2013. Furthermore, Average BOD removal per day during assessment period was found as 1.3, 3.4, 6.0 and $5.7 \mathrm{mg} / \mathrm{L}$. Highest BOD removal was achieved by Canna followed by Lemna, Eichhornia and control. Control treatment showed maximum BOD removal of $7.0 \mathrm{mg} / \mathrm{L}$ between $1^{\text {st }}$ to $3^{\text {rd }}$ day of treatment and a minimum removal of $1.0 \mathrm{mg} / \mathrm{L}$ between both $24^{\text {th }}$ to $27^{\text {th }}$ and $27^{\text {th }}$ to $30^{\text {th }}$ day of treatment. Eichhornia treatment showed varied removal rate among different assessment periods; maximum of $28 \mathrm{mg} / \mathrm{L}$ between $1^{\text {st }}$ to $3^{\text {rd }}$ day of treatment and minimum of $2.0 \mathrm{mg}$ $\mathrm{L}^{-1}$ between $12^{\text {th }}$ to $15^{\text {th }}$ and $15^{\text {th }}$ to $18^{\text {th }}$ day of 
treatments. Eichhornia crassipes could not survive after $15^{\text {th }}$ day of treatment therefore it adversely affected the BOD removal efficiency and resulted into a significant drop in BOD afterwards till the end day of treatment. In Canna treatment, BOD removal showed more fascinating results compared to Eichhornia, Lemna and control treatments. Removal rate fluctuated between 9.0 to $52.0 \mathrm{mg} / \mathrm{L}$ between two consecutive assessment periods. Higher BOD removal was observed during initial treatment periods (upto $12^{\text {th }}$ day of treatment). Maximum BOD removal of $52 \mathrm{mg} / \mathrm{L}$ was recorded in first three days of treatment whereas minimum BOD removal of $9.0 \mathrm{mg} / \mathrm{L}$ was achieved between $18^{\text {th }}$ to $21^{\text {st }}$ day of treatment. Among all three macrophytes selected for the treatment Canna plant showed highest tolerance to pollution stress in terms of its growth and new leaves.

Biochemical Oxygen demand (BOD) is amount of oxygen required by microorganisms for degrading organic waste present in waste water. It reflects amount of pollution present in waste water. Higher BOD results into depletion of oxygen from wastewater and causes anaerobic conditions in wastewater. Microorganisms secrete enzymes which degrade organic matter into simpler nutrients which are further absorbed by macrophytes growing in waste water. Thus microorganisms assist in converting complex organic compounds into simpler ones to be absorbed by macrophytes. Maximum BOD reduction in Canna treatment reflects the higher microbial degradation in this treatment resulting into break down of organic matter into simpler nutrients. Lemna treatment also showed satisfactory results with respect to BOD removal during treatment period. BOD removal rate fluctuated between 9.0 to $35.0 \mathrm{mg} / \mathrm{L}$ between consecutive assessment periods. Like Canna treatment, higher removal rates were observed in first three assessment periods (from $1^{\text {st }}$ to $9^{\text {th }}$ day of treatment) and reached $34.0 \%$ of BOD removal upto this period. Similar results were recorded by Oron et al. (1988), who mentioned that the duckweed contribution for the removal of organic material is due to their ability to direct use of simple organic compounds.

Chemical Oxygen Demand (COD): Chemical oxygen demand is amount of oxygen required to oxidize the organic and inorganic pollution present in waste water. In control treatment COD value was decreased from $350.0 \pm 12.0$ to $306.0 \pm 8.0 \mathrm{mg} / \mathrm{L}$ throughout the assessment period (Fig 9 and Table 2). COD removal rate was observed as $11.3 \%$. Average COD removal was recorded as 1.5 $\mathrm{mg} / \mathrm{L} / \mathrm{day}$. COD removal fluctuated between 1.0 to $7.0 \mathrm{mg} / \mathrm{L}$ between different assessment periods. Maximum removal was recorded between $6^{\text {th }}$ to $9^{\text {th }}$ day of treatment while minimum removal was observed between $27^{\text {th }}$ to $30^{\text {th }}$ day of treatment. On the other hand, Eichhornia treatment showed a decrease in COD from $342.0 \pm 7.9$ to $191.0 \pm 4.5$ $\mathrm{mg} / \mathrm{L}$ during treatment. Total COD removal in this treatment was observed as $44.2 \%$ (Table 5.3) and average COD removal was recorded as 5.0 $\mathrm{mg} / \mathrm{L} /$ day during assessment period. Maximum COD removal of $30.0 \mathrm{mg} / \mathrm{L}$ was observed between $1^{\text {st }}$ to $3^{\text {rd }}$ day of assessment period followed by $3^{\text {rd }}$ to $6^{\text {th }}$ and $21^{\text {st }}$ to $24^{\text {th }}$ days $(19 \mathrm{mg} / \mathrm{L})$ of treatments.

In Canna treatment, COD value dropped from $345.0 \pm 11.0$ to $102.0 \pm 5.4 \mathrm{mg} / \mathrm{L}$ during whole treatment period. Canna treatment recorded highest COD removal rate among all treatments and provided $70.4 \%$ of COD removal during treatment. Average COD removal was achieved as 8.1 $\mathrm{mg} / \mathrm{L} /$ day which were maximum among all three treatments. COD removal ranged from 19.0-44.0 $\mathrm{mg} / \mathrm{L}$ between successive assessment periods. Highest removal $(44.0 \mathrm{mg} / \mathrm{L})$ was achieved on first three days of treatment whereas lowest COD removal $(19.0 \mathrm{mg} / \mathrm{L})$ was observed between $6^{\text {th }}$ to $9^{\text {th }}$ and $12^{\text {th }}$ to $15^{\text {th }}$ day of treatment. A more or less similar trend in COD reduction was observed by Deshmukh et al., 2013. Presence of plants in wastewater can deplete dissolved $\mathrm{CO}_{2}$ during the period of high photosynthetic activity. This photosynthetic activity increases the dissolved oxygen of water, thus creating aerobic conditions in wastewater which favour the aerobic bacterial activity to reduce the BOD and COD (Reddy, 1983).

Dissolved Oxygen (DO): Dissolved oxygen showed a change of $2.20 \pm 0.13$ to $0.5 \pm 0.01 \mathrm{mg} / \mathrm{L}$ in control, $2.20 \pm 0.15$ to $1.10 \pm 0.05 \mathrm{mg} / \mathrm{L}$ in Eichhornia, $2.25 \pm 0.07$ to $1.58 \pm 0.04 \mathrm{mg} / \mathrm{L}$ in Canna and $2.21 \pm 0.07$ to $1.45 \pm 0.03 \mathrm{mg} / \mathrm{L}$ in Lemna treatment (Fig 10 and Table 2). Total drop of DO was recorded as 77.3, 50.0, 29.8 and $34.4 \%$ in control, Eichhornia, Canna and Lemna treatment respectively during treatment period (Table 5.3). Maximum DO drop was observed in control 
followed by Eichhornia, Lemna and Canna. Average daily decrease in DO was observed as 0.1, 0.04, 0.02 and $0.03 \mathrm{mg} / \mathrm{L}$ /day control, Eichhornia, Canna and Lemna respectively.

Dissolved oxygen is utilized by microorganisms during degradation of organic waste from waste water. Continuous decrease in DO level during experimental period suggests that microbial degradation was prominent during experimental period. However DO decrease was lower in macrophyte treatment. This confirms that macrophytes were enriching atmospheric oxygen in the waste water by photosynthesis process. Canna and Lemna plants showed higher photosynthetic activity which contributed to low decrease in DO level in these treatments. The results favours the findings of Mangas-Ramirez and Elias-Gutierrez, 2004 and Perna and Burrows, 2005 but are opposites to Darr et al., 2011 and Shah et al., 2010.

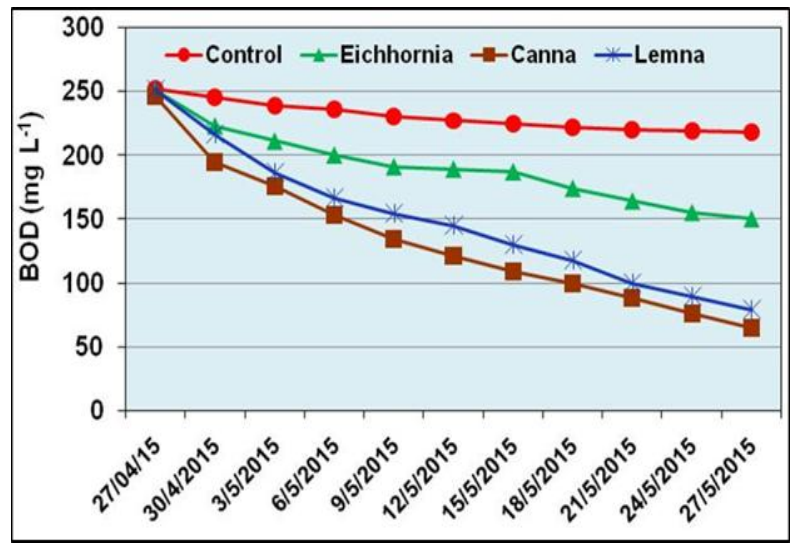

Fig 8. Change in BOD of sewage during the treatment process by Eichhornia, Canna and Lemna.

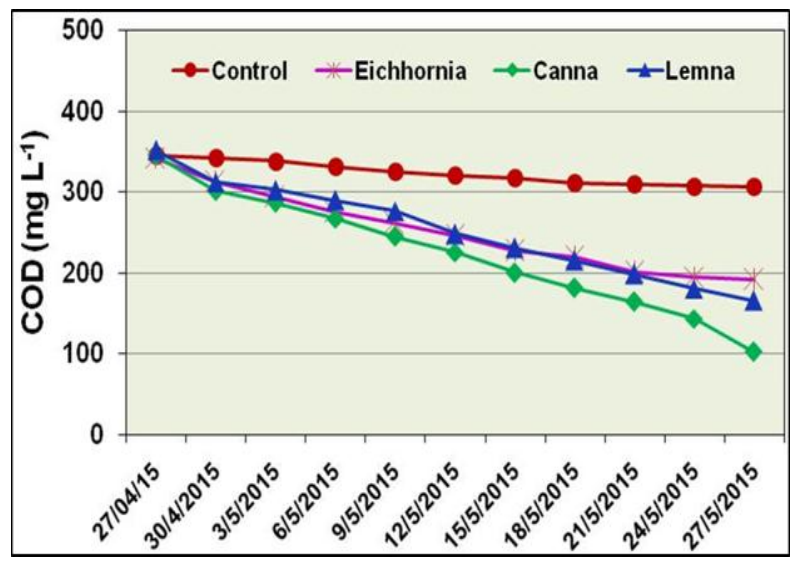

Fig 9. Change in COD of sewage during the treatment process by Eichhornia, Canna and Lemna.

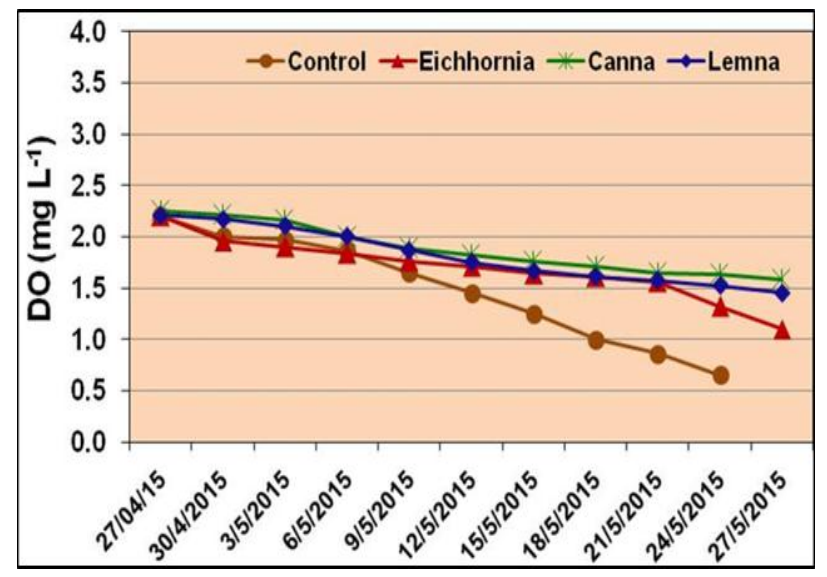

Fig 10. Change in DO of sewage during the treatment process by Eichhornia, Canna and Lemna.

\section{Hardness (as $\mathrm{CaCO}_{3}$ )}

Hardness showed a decrease in all treatments during treatment period as; $230.0 \pm 8.5$ to $183.0 \pm 4.8$ $\mathrm{mg} / \mathrm{L}$ in control; $232.0 \pm 5.6$ to $134.0 \pm 7.6 \mathrm{mg} / \mathrm{L}$ in Eichhornia, $230.0 \pm 8.2$ to $125.0 \pm 2.5 \mathrm{mg} / \mathrm{L}$ in Canna and $236.0 \pm 4.8$ to $137.0 \pm 3.1 \mathrm{mg} / \mathrm{L}$ in Lemna treatment (Fig 12 and Table 2).

Average hardness removal was observed as; 1.8 $\mathrm{mg} / \mathrm{L} /$ day in control, $2.27 \mathrm{mg} / \mathrm{L}$ in Eichhornia, 3.50 $\mathrm{mg} / \mathrm{L}$ in Canna and $3.30 \mathrm{mg} / \mathrm{L}$ in Lemna treatment. Removal range between successive assessment periods varied from 1.0 to $10.0 \mathrm{mg} / \mathrm{L}$ in control, 1.0 to $20.0 \mathrm{mg} / \mathrm{L}$ in Eichhornia, 2.0 to $25.0 \mathrm{mg} / \mathrm{L}$ in Canna and 4.0 to $19.0 \mathrm{mg} / \mathrm{L}$ in Lemna treatment. Hardness removal mechanism is associated with uptake of $\mathrm{Ca}$ and $\mathrm{Mg}$ salts by plants through roots. Similar trend of hardness removal was also observed by Fonseka and Amarasinghe, 2016 and Shah et al., 2010.

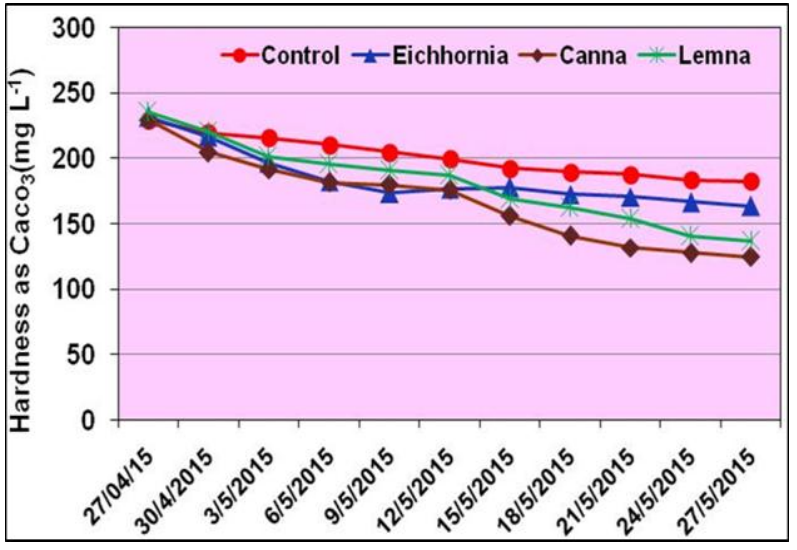

Fig 11. Change in TH of sewage during the treatment process by Eichhornia, Canna and Lemna. 
Phytoremediation efficiency of $E$. crassipes, C. indica and L. minor

Table 2. Showing changes in the physico-chemical properties of sewage before and after the treatment with Eichhornia, Canna and Lemna.

\begin{tabular}{|c|c|c|c|c|c|c|c|c|c|c|c|}
\hline & & pH & $\begin{array}{l}E C \\
(\mu \text { s/cm })\end{array}$ & $\begin{array}{l}\text { ORP } \\
(\mathrm{mV})\end{array}$ & $\begin{array}{l}\text { Do } \\
(\mathrm{mg} / \mathrm{l})\end{array}$ & $\begin{array}{l}\text { temp. } \\
\left({ }^{0} \mathrm{C}\right)\end{array}$ & $\begin{array}{l}\text { TDS } \\
(\mathrm{mg} / \mathrm{l})\end{array}$ & $\begin{array}{l}\text { BOD } \\
(\mathrm{mg} / \mathrm{l})\end{array}$ & $\begin{array}{l}\text { COD } \\
(\mathrm{mg} / \mathrm{l})\end{array}$ & $\begin{array}{l}\text { Hardness } \\
(\mathrm{mg} / \mathrm{l})\end{array}$ & $\begin{array}{l}\text { Salinity } \\
(\mathrm{mg} / \mathrm{l})\end{array}$ \\
\hline \multirow{4}{*}{$27 / 4 / 15$} & Control & 7.64 & 1534 & -69.1 & 2.20 & 21.8 & 983 & 252 & 345 & 230 & 785 \\
\hline & Eichhornia & 7.60 & 1529 & -68.7 & 2.20 & 24.6 & 978 & 251 & 342 & 232 & 757 \\
\hline & Canna & 7.60 & 1534 & -72.5 & 2.25 & 24.6 & 967 & 246 & 345 & 230 & 745 \\
\hline & Lemna & 7.60 & 1545 & -77.2 & 2.21 & 24.6 & 961 & 251 & 351 & 236 & 735 \\
\hline \multirow{4}{*}{$30 / 4 / 15$} & Control & 7.63 & 1532 & -68.7 & 2.00 & 23.1 & 965 & 245 & 342 & 220 & 776 \\
\hline & Eichhornia & 7.57 & 1520 & -69.5 & 1.96 & 23.4 & 961 & 223 & 312 & 217 & 750 \\
\hline & Canna & 7.43 & 1454 & -55.7 & 2.21 & 23.0 & 865 & 194 & 301 & 205 & 719 \\
\hline & Lemna & 7.54 & 1476 & -64.7 & 2.17 & 26.3 & 882 & 216 & 312 & 221 & 720 \\
\hline \multirow{4}{*}{$3 / 5 / 15$} & Control & 7.61 & 1528 & -68.3 & 1.97 & 26.0 & 900 & 239 & 338 & 216 & 763 \\
\hline & Eichhornia & 7.52 & 1453 & -66.8 & 1.90 & 24.4 & 856 & 211 & 293 & 197 & 734 \\
\hline & Canna & 7.41 & 1367 & -47.9 & 2.16 & 26.1 & 715 & 176 & 286 & 192 & 623 \\
\hline & Lemna & 7.51 & 1398 & -56.1 & 2.10 & 23.0 & 803 & 186 & 302 & 202 & 678 \\
\hline \multirow{4}{*}{$6 / 5 / 15$} & Control & 7.62 & 1521 & -68.0 & 1.86 & 26.0 & 893 & 236 & 331 & 211 & 755 \\
\hline & Eichhornia & 7.48 & 1387 & -63.1 & 1.84 & 26.4 & 743 & 200 & 275 & 183 & 700 \\
\hline & Canna & 7.36 & 1276 & -38.6 & 2.00 & 26.6 & 634 & 153 & 267 & 182 & 537 \\
\hline & Lemna & 7.46 & 1338 & -51.6 & 2.00 & 25.5 & 725 & 166 & 289 & 196 & 587 \\
\hline \multirow{4}{*}{$9 / 5 / 15$} & Control & 7.59 & 1518 & -65.3 & 1.65 & 26.4 & 882 & 230 & 325 & 205 & 752 \\
\hline & Eichhornia & 7.44 & 1169 & -62.5 & 1.76 & 26.4 & 569 & 191 & 261 & 174 & 515 \\
\hline & Canna & 7.31 & 1145 & -27.8 & 1.89 & 26.1 & 543 & 134 & 244 & 180 & 428 \\
\hline & Lemna & 7.37 & 1246 & -42.8 & 1.87 & 26.0 & 650 & 154 & 276 & 191 & 516 \\
\hline \multirow{4}{*}{$12 / 5 / 15$} & Control & 7.55 & 1511 & -61.0 & 1.45 & 26.9 & 875 & 227 & 320 & 200 & 752 \\
\hline & Eichhornia & 7.39 & 1100 & -55.4 & 1.71 & 26.9 & 496 & 189 & 245 & 177 & 412 \\
\hline & Canna & 7.24 & 1032 & -22.2 & 1.82 & 26.9 & 474 & 121 & 225 & 176 & 387 \\
\hline & Lemna & 7.28 & 1162 & -33.7 & 1.75 & 25.6 & 572 & 145 & 248 & 187 & 467 \\
\hline \multirow{4}{*}{$15 / 5 / 15$} & Control & 7.45 & 1509 & -58.7 & 1.25 & 24.7 & 872 & 225 & 317 & 193 & 743 \\
\hline & Eichhornia & 7.31 & 1025 & -45.6 & 1.64 & 23.9 & 356 & 187 & 227 & 178 & 323 \\
\hline & Canna & 7.21 & 965 & -19.8 & 1.76 & 24.6 & 400 & 109 & 200 & 156 & 319 \\
\hline & Lemna & 7.27 & 1065 & -28.1 & 1.67 & 27.1 & 493 & 130 & 230 & 169 & 387 \\
\hline \multirow{4}{*}{$18 / 5 / 15$} & Control & 7.43 & 1502 & -58.1 & 1.00 & 25.4 & 867 & 222 & 311 & 190 & 736 \\
\hline & Eichhornia & 7.29 & 1010 & -39.7 & 1.61 & 25.5 & 351 & 174 & 219 & 173 & 301 \\
\hline & Canna & 7.19 & 876 & -18.6 & 1.71 & 25.1 & 359 & 100 & 181 & 141 & 277 \\
\hline & Lemna & 7.25 & 954 & -23.4 & 1.61 & 24.1 & 423 & 118 & 215 & 163 & 312 \\
\hline \multirow{4}{*}{$21 / 5 / 15$} & Control & 7.38 & 1497 & -52.3 & 0.86 & 28.1 & 866 & 220 & 309 & 188 & 732 \\
\hline & Eichhornia & 7.23 & 985 & -36.6 & 1.56 & 28.3 & 347 & 164 & 200 & 171 & 298 \\
\hline & Canna & 7.14 & 800 & -17.7 & 1.65 & 28.4 & 315 & 88 & 164 & 132 & 211 \\
\hline & Lemna & 7.20 & 900 & -20.5 & 1.57 & 25.5 & 382 & 100 & 198 & 154 & 267 \\
\hline
\end{tabular}




\section{Bhutiani et al.}

\section{Conclusion}

Present study revealed that phytoremediation is an effective technology for treatment of sewage waste water. Among all three macrophytes, Canna indica showed maximum reductions in EC, TDS, BOD, COD, hardness and salinity. pH showed a decrease in all treatments with maximum decrease in Canna treatment followed by Lemna and Eichhornia. After $15^{\text {th }}$ day of treatment Eichhornia plant could not survive in waste water which resulted into a drop in removal efficiency in Eichhornia treatment. This suggests that Macrophytes play an important role in absorbing contaminants from waste water through their roots. Further, following conclusions are taken out from the present study. Many factors such as temperature, $\mathrm{pH}$, solar radiation, and salinity of the water influence plant growth and its phytoremediation performance. During the present study among all the three selected macrophytes $C$. indica was found most efficient in the treatment of sewage. The harvesting of macrophytes after maturation is necessary because if the plant died in the water body, the degradation of plants results in the leaching of absorbed nutrients into the water again.

\section{References}

APHA, AWWA WPCF, 2012. Standard methods for the examination of water and waste water. American Public Health Association, Washington $14^{\text {th }}$ Edition. N. York. 193.

APIRIS, 2005. Invasive Non indigenous Plants in Florida., Online Available: http://plants.ifas.ufl.edu/hyacin2.html

Bhutiani, R., Khanna, D. R., Shubham and Ahamad, F. 2016. Physico-chemical analysis of Sewage water treatment plant at Jagjeetpur, Haridwar, Uttarakhand. Environ. Cons. Jour., 17(3): 133-142.

Bhutiani, R. and Ahamad, F. 2018. Efficiency assessment of Sand Intermittent Filtration Technology for waste water Treatment. International Journal of advance research in science and engineering (IJARSE), 7(03): 503-512.

Borges, A. K. P., Tauk-Tornisielo, S. M., Domingos, R. N. and Angelis, D. F. 2008. Performance of the constructed wetland system for the treatment of water from the Corumbatai river., Braz. Arch. Biol. Technol., 51(6): $1279-1286$.

Cunningham, S. D., William, R. B. and Jianwei, W. H. 1995. Phytoremediation of contaminated soils, Tibtech, 13: 393397.
Dar, S. H., Kumawat, D. M., Singh, N. and Wani, K. A. 2011. Sewage treatment potential of water hyacinth (Eichhornia crassipes). Res. J. Environ. Sci., 5(4): 377-385.

Deshmukh , A. A., Bandela, N. N., Chavan, J. R. and Nalawade, P. M. 2013. Studies on Potential Use of Water Hyacinth, Pistia and Azolla for Municipal Waste Water Treatment. Environment, 3(11): 226-228.

Dhote, S. and Dixit, S. 2007. Water quality improvement through macrophytes: A case study., Asian J. Exp. Sci., 21(2): 427-430.

Dhote, S. and Dixit, S. 2009. Water quality improvement through macrophytes- A review. Environ. Monit. Assess., 152: $149-153$.

ENVIS Centre on Hygiene, Sanitation, Sewage Treatment Systems and Technology,http://www.sulabhenvis.nic.in/Database/STST _wastewater_2090.aspx

Fonseka, S. and Amarasinghe, D. 2016. Characterization of ground water hardness with special reference to Polpithigama Divisional Secretariat Area in Kurunegala district and potential use of plants to reduce water Hardness. Thesis submitted to department of Botany and the department of Chemistry, University of Kelaniya.

Greongerg, A. E., Connors, J. E., Jinkins, D. and Fransons, M. A. 1995. Standard methods for the examination of water and waste water (15th ed., pp. 199-209). Washington DC: American Public Health Association, APHA.

IWMI, 2003-2004. International Water Management Institute annual report.

Jamuna, S. and Noorjahan, C. M. 2009. Treatment of sewage waste water using water hyacinth - Eichhornia sp and its reuse for fish culture. Toxicol. Int., 16(2): 103-106.

John, R., Ahmad, P., Gadgil, K. and Sharma, S. 2008. Effect of cadmium and lead on growth, biochemical parameters and uptake in Lemna polyrrhiza L. Plant Soil Environ., 54: 262-270.

Khanna, D. R. and Bhutiani, R. 2008. Laboratory manual of water and Waste water Analysis. Daya Publishing House New Delhi -110002.

Kumar, V., Chopra, A. K. 2016. Reduction of pollution load of paper mill effluent by phytoremediation technique using water caltrop (Trapa natans L.). Cogent Environmental Science, 2: 1153216.

Kumar, V., Chopra, A. K., Singh, J., Thakur, R. K., Srivastava, S., and Chauhan, R. K. 2016. Comparative assessment of phytoremediation feasibility of water caltrop (Trapa natans L.) and water hyacinth (Eichhornia crassipes Solms.) using pulp and paper mill effluent. Archives of Agriculture and Environmental Science, 1(1): 13-21. 
Kumar, V., Chopra, A. K., Singh, J., Thakur, R. K., Srivastava, S. and Chauhan, R. K. 2017b. Comparative assessment of phytoremediation feasibility of water caltrop (Trapa natans L.) and water hyacinth (Eichhornia crassipes Solms.) using pulp and paper mill effluent. Archives of Agriculture and Environmental Science, 1(1): 13-21.

Kumar, V., Singh, J. and Chopra, A. K. 2017a. Assessment of phytokinetic removal of pollutants of paper mill effluent using water hyacinth (Eichhornia crassipes [Mart.] Solms), Environmental Technology, https://doi.org/ 10. 1080/ 09593330.2017.1365944

Landolt, E., (Ed.), 1980. Biosystematic investigations in the family of duckweeds(Lamnaceae), Veroffentlichungen des Geobotanischem institutes der ETH 1. Geobotanischen institutes, Stiftung Rubel, Zurich, 247.

Landolt, E., (Ed.), 1986. The family of Lamnaceae: A monographic Study (Vol. 1), Biosystematic investigation in the family of Duckweeds, Veroffentlichungen des Geobotanischen Institutes der ETH1, Geobotanyschen Institutes, Stiftung Rubel, Zurich, 566.

Landolt, E., 1982. Distribution pattern within the family Lamnaceae. In: Symoens, J.J., Hooper, S.S., Compere, P.,(EdS.) Studies on aquatic vascular plants, Royal Botanic Society of Belgium, Brussels, 313-321.

Les, D. H., Landolt, E., Gabel, J. D. and Kemball, R. T. 2002 Phylogeny and systematics of Lamnaceae, the duckweed family. Systematic Botany, 27: 221-240.

Mahmood, Q., Zheng, P., Islam, E., Hayat, Y., Hassan, M. J., Jilani, G. and Jin, R.C. 2005. Lab scale studies on water hyacinth (Eichhornia crassipes marts solms) for biotreatment of textile wastewater. Caspian Journal of Environmental 3(2): 83-88.

Maine, M. A., Sune, N. L. and Lagger, S. C. 2004. Chromium bioaccumulation: Comparison of the capacity of two floating aquatic macrophytes. Water Res., 38: 1494-1501.

Mangas-Ramirez, E. and Elias-Gutierrez, M. 2004. Effect of mechanical removal of water hyacinth (Eichhornia crassipes) on the water quality and biological communities in a Mexican reservoir., J. Aquat. Ecosys. Health Manage., 7: $161-168$

Mishra, V. K., Upadhyay, A. R., Pandey, S. K. and Tripathi, B.D. 2008. Concentrations of heavy metals and aquatic macrophytes of Govind Ballabh Pant Sagar an anthropogenic lake affected by coal mining effluent. Environ. Monit. Assess., 141: 49-58.

Mkandawire, M. and Dudel, E. G., 2005b. Assignment of Lemna gibba L., (duck-weed) bioassay for in situ ecotoxicity assessment. Aquatic Ecology, 39: 151-165.

Mkandawire, M. and Dudel, E. G. 2005a. Accumulation of arsenic in Lemna gibba L. (duckweed) in tailing waters of two abandoned uranium mines in Saxony, Germany, Science of the Total Environment, 336: 81-89.

Nieder, W.C., Barnaba, E., Findlay, S. E. G., Hoskins, S. Holochuck, N. and Blair. E. A. 2004. Distribution and abundance of submerged aquatic vegetation and Trapa natans in the Hudson River Estuary. J. C. Res., 45: 150161.

Oron, G., De Vegt, A. and Porath, D. 1988. Nitrogen removal and conversion by duckweed grown on wastewater. Water Res., 22: 179-84.

Padmapriya, G., and Murugesan, A. G. 2012. Phytoremediation of various heavy metals $(\mathrm{Cu}, \mathrm{Pb}$ and $\mathrm{Hg})$ from aqueous solution using water hyacinth and its toxicity on plants. International Journal of Environmental Biology, 2(3): 97-103.

Patil, J. H., Raj, M. L. A, Bhargav S. and Sowmya S. R. 2011. Anaerobic co-digestion of water hyacinth with primary sludge. Res. J. Chem. Sci., 1 (3): 72-77.

Perna, C. and Burrows, D., 2005. Improved dissolved oxygen status following removal of exotic weed mats in important fish habitat lagoons of the tropical Burdek in river floodplain, Australia., Marine Poll. Bull., 51: 138-148.

Reddy, K. R. 1983. Fate of nitrogen and phosphorus in wastewater retention reservoir containing aquatic macrophytes. J. Environ. Qual., 12:137- 141.

Reddy, K. R. and Sutton, D. L. 1984. Water hyacinths for water quality improvement and biomass production. $\boldsymbol{J}$. Environ. Qual., 13(1): 1-9.

Roongtanakiat, N., Tangruangkiat, S. and Meesat, R. 2007. Utilization of vetiver grass (Vetiveria zizanioides) for removal of heavy metals from industrial wastewaters. Science Asia, 33: 397-403.

Schulz, M., Rinle, K., and Kohler, J. 2003. A combined approach of photogrammetrical methods and field studies to determine nutrient retention by submersed macrophytes in running waters. Aquat. Bot., 76(1): 17-29.

Selvarathi, P. and Ramasubramanian, V. J. 2010. Phytoremedial effect of Datura metel L. on paper mill effluent and its impact on Physicochemical characteristics of Lycopersicon esculentum Mill. Bioscience Research, 1(2): 94-100.

Shah, R.A., Kumawat, D. M., Singh, N. and Wani, K. A. 2010. Water hyacinth (Eichhornia crassipes) as a remediation tool for dye-effluent pollution., Int. J. Sci. Nature, 1(2): 172178.

Singh, O. V., Labana, S., Pandey, G., Budhiraja, R., Jain, R. K. 2003. Phytoremediation: An overview of metallic ion decontamination from soil. Appl. Microbiol. Biotechnol., 61: 405-412. 
Sooknah, R. D., and Wilkie, A. C. 2004. Nutrient removal by floating aquatic macrophytes cultured in anaerobically digested flushed dairy manure wastewater. Ecological Engineering, (22): 27- 42.

Stefani, G. D., Tocchetto, D., Salvato, M. and Borin, M. 2011. Performance of a floating treatment wetland for in-stream water amelioration in NE Italy. Hydrobiologia, 674: 157167.

Trivedi, R. K. and Goel, P. K. 1986. Chemical and biological methods for water pollution studies. Environmental publications; $1-250$.

USEPA, 1988. Design Manual - Constructed wetlands and aquatic systems for municipal wastewater treatment, United States Environmental Protection Agency, Report no. EPA/625/1-88/022, Office of Research and Development, Cincinnati, $\mathrm{OH}, 83$.
Villamagna, A. M. 2009. Ecological effects of water hyacinth (Eichhornia crassipes) on lake Chapala, Mexico, Ph.D Thesis, Fisheries and Wildlife Sciences, Virginia Polytechnic Institute and State University, Blacksburg, Virginia.

Wolverton, B. C. and McDonald, R. C. 1979. The water hyacinth: from prolific pest to potential provider. Ambio, 8: $1-12$.

Xia, H. and Ma, X. 2006. Phytoremediation of ethion by water hyacinth (Eichhornia crassipes) from water. Bioresource Technol., 97: 1050-1054. 